\title{
Prevalence and influencing factors of BMI and effect of school based intervention among the Grade 8 Schoolchildren in Jaffna district
}

Surenthirakumaran $R^{1}$, Coonghe P.A.D ${ }^{1}$, Kumaran $S^{1}$

${ }^{1}$ Department of Community and Family Medicine, Faculty of Jaffna, University of Sri Lanka

\begin{abstract}
Overweight and obesity are becoming a global issue. In contrast, children living in developing countries like Sri Lanka are having problems with wasting. Understanding the status of wasting, overweight and obesity and underlying factors may help to address the issue.
\end{abstract}

The study aimed to determine the prevalence of wasting, overweight and obesity and the underlying socio-demographic and school-related correlate and effect pf school-level intervention to manage wasting, overweight and or obesity among Sri Lankan school children

A school based descriptive cross-sectional study was conducted among 836 students aged between 13-15 years studying at government schools in Jaffna district from June 2016 to November 2017. Anthropometric measurements obtained using electronic height weight machine with the precision of the instrument for height is $\leq \pm 0.1 \mathrm{~cm}$, and for weight is $\leq \pm 0.1 \mathrm{~kg}$, and the Body Mass Index (BMI) for age calculated and compared with WHO (2007) standards. Chi-square analyses performed, and odds ratios calculated in SPSS 21.

\section{Results}

Slightly males students (51.4\%) were more than the female students. Majority of the students were Hindus (91.1\%), and living with both parents (87.2\%). The prevalence of wasting, overweight and obesity was $38.6 \%, 6.8 \%$ and $2.4 \%$ respectively. Having abnormal BMI was not significantly affected the participation in extracurricular activities.

High prevalence of abnormal BMI observed, and none of the school-level interventions for abnormal BMI were not useful. Hence, periodical assessment and monitoring of the school-based program might improve the outcome.

\section{Key word}

Overweight, Obesity, Jaffna, Sri Lanka, school health

\section{Introduction}

As a transition period of the child to become adult, adolescence is a decisive period of development. The changes that happening also affect the amount and type of food intake, which has an impact on lifetime nutritional status. As and Body mass in$\operatorname{dex}(\mathrm{BMI})$ is the recommended simple method for diagnosing wasting, overweight and obesity. It is a measure of general health based on height and weight ratio (1). Globally, the prevalence of overweight and obesity among children and adolescents aged 5-19 has risen dramatically from just 4\% in 1975 to just over $18 \%$ in 2016. The similar trend observed among the boys and girls (3).

Wasting affects more children and adolescents than obesity. The underweight population had 19.7\% greater risk of cardiovascular diseases than did the normal-weight (4). 
Several factors influence the level of health in children, such as social environment, their education, personal health practices, healthy child development, and culture (3). The overweight and obese population had 50 and $96 \%$ greater risk of Cardiovascular Diseases respectively than did the normal weight (4). Schools are considered as the easy and primary platform to conduct health and nutrition intervention programs. Unfortunately, school-based programs are struggling to achieve the expected outcomes due to various constraints. Sri Lankan school-based health programs introduced in early 1918 in Colombo Municipality area and further expanded with the development of public health services of Sri Lanka. Several new components added based on the need. Limited evidence is available about the outcomes of the programme (5).

Jaffna is one of the districts Northern Province of Sri Lanka which was severely affected by the protracted ethnic conflict and recovering from the effect of the war. New developments that are taken place in the district, mostly open to the world market create new opportunities to change the behaviour and eating habits of the children, which could affect the nutritional status of the children. The aim of the study is to determine the prevalence of wasting overweight and obesity and the underlying socio-demographic and school-related correlate and effect school-level intervention to manage wasting, overweight and or obesity among Sri Lankan.

\section{Methods}

A school based descriptive cross-sectional study was conducted among 871 adolescents aged between 13-15 years studying in Grade 8, 9 \& 10 at government schools in Jaffna district of Sri Lanka during June 2016 to November 2017. There are four types of school in Sri Lanka, i. e: 1
$\mathrm{AB}, 1 \mathrm{C}, 2$ and 3 (1 AB - school having advanced level science stream classes, $1 \mathrm{C}$ - school having advanced level Arts and /or Commerce streams but no science stream, 2 - schools having classes only up to grade 11,3 - schools having classes only up to grade 8 . Height and weight were measured using an electronic height weight machine. This instrument measured height between the range of $70-200 \mathrm{~cm}$ and the weight value between the ranges of $5-250 \mathrm{~kg}$. The precision of the instrument for height measurement is $\leq \pm 0.1 \mathrm{~cm}$, and for weight is $\leq \pm 0.1 \mathrm{~kg}$. Self-administrated questionnaire was used to collect socio-demographic factors, school level interventions and details of students' performances. Data entered to SPSS 21 for analysis purpose. The Body Mass Index (BMI) for age calculated and compared with WHO (2007) standards: Overweight: >+1SD (equivalent to BMI 25 $\mathrm{kg} / \mathrm{m} 2$ at 19 years), Obesity: $>+2 \mathrm{SD}$ (equivalent to BMI $30 \mathrm{~kg} / \mathrm{m} 2$ at 19 years), wasting: <-2sd> . The bivariable analysis was done by including the Wasting, overweight and obesity as abnormal BMI category and compared with the normal BMI category (6). Chi-square test performed, and the odds ratios calculated. P-value $<0.05$ considered as statistically significant, and $95 \%$ confidence intervals calculated. Ethical approval was obtained from the ethical committee of Faculty of Medicine, University of Jaffna J/ERC/15/65/NDR/0132.

\section{Results}

\section{Socio-demographic factors of the study partic- ipants}

Among the study participants, the gender ratio was almost equal to Males (51.4\%) and Females (48.6\%). All the children were Tamils, and the majority (91.1\%) were Hindus. More than $85 \%$ of the children were living with both parents. Nearly $32 \%$ of both parents of the children had education up to G.C.E (O/L). Majority of the mothers were 
housewives (77.2\%), and fathers were in elementary occupation (62.7\%). Majority of the children were living in a nuclear family $(75.0 \%)$, living with both parents $(87.2 \%)$, and living with $4-8$ nos. of family members $(70.6 \%)$ (Table 1$)$.

Table 1: Details of socio demographic factors of study participants

\begin{tabular}{|c|c|}
\hline Socio demographic factors & Number (\%) \\
\hline Gender, male & $430(51.4)$ \\
\hline Religion, Hinduism & $762(91.1)$ \\
\hline \multicolumn{2}{|l|}{ Father's educational level } \\
\hline Up to G.C.E O/L & $265(31.7)$ \\
\hline Up to G.C.E (A/L) & $154(18.4)$ \\
\hline Degree/diploma & $92(11.0)$ \\
\hline Not reported & $325(38.9)$ \\
\hline \multicolumn{2}{|l|}{ Mother's educational level } \\
\hline Up to G.C.E O/L & $257(30.7)$ \\
\hline Up to G.C.E (A/L) & $224(26.8)$ \\
\hline Degree/diploma & $108(12.9)$ \\
\hline Not reported & $247(29.5)$ \\
\hline \multicolumn{2}{|l|}{ Father's occupation } \\
\hline Officer $\&$ administrative & $83(9.9)$ \\
\hline Technicians \& clerk & $26(3.1)$ \\
\hline \multirow{3}{*}{$\begin{array}{l}\text { Skilled workers } \\
\text { Elementary occupation* } \\
\text { Not identified }\end{array}$} & $85(10.2)$ \\
\hline & $524(62.7)$ \\
\hline & $118(14.1)$ \\
\hline \multicolumn{2}{|l|}{ Mother's occupation } \\
\hline Officer $\&$ administrative & $96(11.5)$ \\
\hline Technicians \& clerk & $22(2.6)$ \\
\hline Skilled workers & $4(0.5)$ \\
\hline \multirow{2}{*}{$\begin{array}{l}\text { Elementary occupation } \\
\text { House wife }\end{array}$} & $69(8.3)$ \\
\hline & $645(77.2)$ \\
\hline Living in nuclear family & $627(75.0)$ \\
\hline $\begin{array}{l}\text { Living in home/ children's' } \\
\text { home } \\
\text { Living with both parents } \\
\text { Living in Children's home }\end{array}$ & $\begin{array}{l}729(87.2) \\
14(1.7)\end{array}$ \\
\hline \multicolumn{2}{|l|}{ Number of family members } \\
\hline 4 & $221(26.4)$ \\
\hline $5-8$ & $590(70.6)$ \\
\hline$>8$ & $25(3.0)$ \\
\hline
\end{tabular}

*Elementary occupations consist of simple and routine tasks which mainly require the use of hand-held tools and often some physical effort.

\section{Description of facilities available in schools and students' performance}

Majority of the children (94.0\%) were studying in $1 \mathrm{AB}$ school, and almost all the students reported that they received vitamin $\mathrm{C}(95.3 \%)$, iron (93.7\%), followed by vitamin A (69.0\%) and then folic acid $(65.8 \%)$. More than ninety percent of the schools had school health club (94.7\%) and counselling health teachers $(93.1 \%)$, further majority of the students (76.6\%) involved in extracurricular activities. (Table 2).

Table 2. Description of school facilities and per formance of the students

\begin{tabular}{|l|l|}
\hline $\begin{array}{l}\text { School facilities and performance } \\
\text { of the students }\end{array}$ & Number (\%) \\
\hline Type of school & $786(94.0)$ \\
\hline $1 \mathrm{AB}$ & $37(4.4)$ \\
\hline $1 \mathrm{C}$ & $13(1.6)$ \\
\hline 2 & $783(93.7)$ \\
\hline Received iron supplementation & $797(95.3)$ \\
\hline $\begin{array}{l}\text { Received Vitamin C supplemen- } \\
\text { tation }\end{array}$ & $577(69.0)$ \\
\hline $\begin{array}{l}\text { Received Vitamin A supplemen- } \\
\text { tation }\end{array}$ & $550(65.8)$ \\
\hline $\begin{array}{l}\text { Received Folic acid supplemen- } \\
\text { tation }\end{array}$ & $778(93.1)$ \\
\hline Had counseling teacher & $792(94.7)$ \\
\hline Had a school health club & $640(76.6)$ \\
\hline $\begin{array}{l}\text { Participated in Extracurricular } \\
\text { activities }\end{array}$ & $335(40.1)$ \\
\hline Participated in sports meet & $404(48.3)$ \\
\hline Participated in school sports team & \\
\hline
\end{tabular}

\section{Nutritional status distribution among the students}

Among the study participants, the prevalence of wasting, overweight, and obesity was more than fifty percent (52.2\%), while $38.6,6.8$ and $2.4 \%$ of the students were of respectively (Table 3 ).

Jaffna Medical Journal 
Table 3. Distribution of obesity status among the study participants

\begin{tabular}{|l|l|l|}
\hline Obesity Status & Frequency & Percentage \\
\hline Thinness & 323 & 38.6 \\
\hline Normal & 436 & 52.2 \\
\hline overweight & 57 & 6.8 \\
\hline Obese & 20 & 2.4 \\
\hline
\end{tabular}

\section{Relationship between level of BMI and the so- cio-demographic factor}

Table 4 shows the relationship between the socio-demographic factors and level of BMI among the participants. Among 400 students of having underweight, overweight and or obesity, males had the chance of having abnormal BMI as 1.402 times than females (odds ratio $=1.402$, CI 95\% 1.2101.623 ) and gender got a statistically significant influence on BMI level ( $p<0.001)$.. Almost 50\% of the students from Hindu and Christian religion had abnormal BMI.

Further, the students of both parents (Father-OR1.033, 95\% CI: 0.883- 1.209), (Mother-OR1.096, 95\% CI:0.945-1.270) had education up to G.C.E. (O/L), had high chance of having abnormal BMI. In contrast, chance of having irregular BMI of students of fathers and mothers who were elementary workers and housewives respectively was low. Regarding rearing pattern, chance of getting underweight, overweight, and obesity had not been decreased even though the students were living with both parents, and living in nuclear families, while the student living with less than five family members had low chance of getting such abnormal BMI as mentioned in table 4 .

Table 4. Relationship between the level of BMI and socio demographic factors

\begin{tabular}{|c|c|c|c|c|c|c|}
\hline Socio-demographic factor & Variable & Normal BMI & $\begin{array}{l}\text { Abnormal } \\
\text { BMI }\end{array}$ & $P$ value & Odd ratio & CI $(95 \%)$ \\
\hline \multirow[t]{2}{*}{ Sex } & Male & $191(44.4)$ & $239(55.6)$ & $0.000 *$ & 1.402 & $1.210-1.623$ \\
\hline & Female & $245(60.3)$ & $161(39.7)$ & & & \\
\hline \multirow[t]{2}{*}{ Religion } & Hindu & $399(51.0)$ & $383(49.0)$ & 0.698 & 0.980 & $0.771-1.244$ \\
\hline & Christianity & $37(50.0)$ & $37(50.0)$ & & & \\
\hline \multirow[t]{2}{*}{ Both parents living together } & Yes & $375(51.4)$ & $354(48.6)$ & 0.165 & 1.130 & $0.897-1.423$ \\
\hline & No & $61(57.0)$ & $46(43.0)$ & & & \\
\hline \multirow[t]{2}{*}{ Father's education status } & $\begin{array}{l}\text { Up to G.C.E } \\
(\mathrm{O} / \mathrm{L})\end{array}$ & $305(51.7)$ & $285(48.3)$ & 0.369 & 1.033 & $0.883-1.209$ \\
\hline & 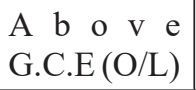 & $131(53.2)$ & $115(46.8)$ & & & \\
\hline \multirow[t]{2}{*}{ Mother's education status } & $\begin{array}{l}\text { Up to G.C.E } \\
(\mathrm{O} / \mathrm{L})\end{array}$ & $254(50.5)$ & $249(49.5)$ & 0.124 & 1.096 & $0.945-1.270$ \\
\hline & $\begin{array}{l}\text { A } \quad \text { b } \quad \text { o } \quad v \quad \text { e } \\
\text { G.C.E }(\mathrm{O} / \mathrm{L})\end{array}$ & $182(54.8)$ & $150(45.2)$ & & & \\
\hline \multirow[t]{2}{*}{ Type of Family } & Nuclear & $329(52.4)$ & $298(47.6)$ & 0.405 & 1.159 & $0.990-1.357$ \\
\hline & Extended & $107(51.1)$ & $102(48.9)$ & & & \\
\hline \multirow[t]{2}{*}{ Number of members in the family } & $<5$ & $117(52.9)$ & $104(47.1)$ & 0.423 & 0.819 & $0.699-0.959$ \\
\hline & $\geq 5$ & $319(51.9)$ & $296(48.1)$ & & & \\
\hline \multirow[t]{2}{*}{ Father's occupation } & Officers & $110(56.7)$ & $84(43.3)$ & 0.086 & 0.880 & $0.735-1.052$ \\
\hline & $\begin{array}{l}\text { Elementary } \\
\text { workers }\end{array}$ & $326(50.8)$ & $316(49.2)$ & & & \\
\hline \multirow[t]{2}{*}{ Mother's occupation } & $\begin{array}{l}\text { Working } \\
\text { mothers }\end{array}$ & $108(56.5)$ & $83(43.5)$ & 0.097 & 0.884 & $0.739-1.058$ \\
\hline & Housewives & $328(50.8)$ & $317(49.2)$ & & & \\
\hline
\end{tabular}

*- statistically significant $(p<0.050)$ 
Relationship between level of BMI, school level interventions, and performance of students

Table 5 illustrates the relationship between BMI distribution and school type, students' performance and school-level interventions to protect the students from getting abnormal BMI. Among the students studying in $1 \mathrm{AB}$ school, a majority $(52.8 \%)$ were having average weight and bivariate analysis illustrated that syllabus available in Science subjects of G.C.E (A/L) in $1 \mathrm{AB}$ schools protect from experiencing abnormal BMI among students as 0.814 times (Table 4). Abnormal BMI distribution was high among the students who were provided with vitamin C (OR 1.457, 95\% CI: 0.929- 2.284) and folic acid (OR 1.021, 95\% CI: 0.878- 1.186), while iron and vitamin A supplementation reduces the chance of getting abnormal BMI (Table 5). However, availability of school health club and counselling facility did not protect the students from getting wasting, overweight or obesity. Regarding the performance of students in school, even though the students with slightly more percentage of abnormal BMI students (48.2\%) could take part in extracurricular activities compare to the participation in sports meet $(47,2 \%)$ and sports team $(47.5 \%)$. None of the observed difference was not significant at $\mathrm{p}$-value 0.05 .

Table 5. Relationship between the level of BMI, school level interventions, and students' performance.

\begin{tabular}{|c|c|c|c|c|c|c|}
\hline School-related factor & Variable & Normal BMI & Abnormal BMI & Pvalue & Odd ratio & CI $(95 \%)$ \\
\hline \multirow[t]{2}{*}{ Type of school } & $1 \mathrm{AB}$ & $415(52.8)$ & $371(47.2)$ & 0.091 & 0.814 & $0.636-1.042$ \\
\hline & $1 \mathrm{C} \& 2$ & $21(42.0)$ & $29(58.0)$ & & & \\
\hline \multirow{2}{*}{ Provision of iron supplementation } & Yes & $404(51.6)$ & $379(48.4)$ & 0.216 & 0.997 & $0.900-1.104$ \\
\hline & No & $32(60.4)$ & $21(39.6)$ & & & \\
\hline \multirow{2}{*}{$\begin{array}{l}\text { Provision of Vitamin C supple- } \\
\text { mentation }\end{array}$} & Yes & $410(51.4)$ & $387(48.6)$ & 0.063 & 1.457 & $0.929-2.284$ \\
\hline & No & $26(66.7)$ & $13(33.3)$ & & & \\
\hline \multirow{2}{*}{$\begin{array}{l}\text { Provision of Vitamin A supple- } \\
\text { mentation }\end{array}$} & Yes & $301(52.2)$ & $276(47.8)$ & 0.991 & 0.999 & $0.857-1.164$ \\
\hline & No & $135(52.1)$ & $124(47.9)$ & & & \\
\hline \multirow{2}{*}{$\begin{array}{l}\text { Provision of Folic acid supple- } \\
\text { mentation }\end{array}$} & Yes & $285(51.8)$ & $265(48.2)$ & 0.788 & 1.021 & $0.878-1.186$ \\
\hline & No & $151(52.8)$ & $135(47.2)$ & & & \\
\hline \multirow{2}{*}{ Having a school health club } & Yes & $408(51.5)$ & $384(48.5)$ & 0.078 & 1.333 & $0.896-1.984$ \\
\hline & No & $28(63.6)$ & $16(36.4)$ & & & \\
\hline \multirow{2}{*}{$\begin{array}{l}\text { Availability of } \\
\text { Counselling teacher }\end{array}$} & Yes & $401(51.5)$ & $377(48.5)$ & 0.123 & 1.222 & $0.882-1.692$ \\
\hline & No & $35(60.3)$ & $23(39.7)$ & & & \\
\hline \multirow[t]{2}{*}{ Extracurricular activities } & Yes & $340(51.8)$ & $316(48.2)$ & 0.392 & 0.940 & 0.78 to 1.39 \\
\hline & No & $96(53.3)$ & $84(46.7)$ & & & \\
\hline \multirow[t]{2}{*}{ Participation in sports meet } & Yes & $177(52.8)$ & $159(47.2)$ & 0.400 & 1.040 & $1.041-1.366$ \\
\hline & No & $259(51.7)$ & $242(48.3)$ & & & \\
\hline \multirow[t]{2}{*}{ Participation in a school sports team } & Yes & $212(52.5)$ & $192(47.5)$ & 0.890 & 1.03 & 0.77 to 1.36 \\
\hline & No & $224(51.9)$ & $208(48.1)$ & & & \\
\hline
\end{tabular}




\section{Discussion}

In this study $28.6(\mathrm{n}=239)$ and $19.3 \%(\mathrm{n}=161)$ male and female students were having abnormal BMI: Overweight: $>+1 \mathrm{SD}$ (equivalent to BMI $25 \mathrm{~kg} / \mathrm{m} 2$ at 19 years), Obesity: >+2SD (equivalent to BMI 30 $\mathrm{kg} / \mathrm{m} 2$ at 19 years), wasting: $<-2 \mathrm{SD}$, i.e. the prevalence of abnormal BMI is high among male students than females. It might be due to the self-perception of female students' body weight may influence their weight management in a healthy range. However, the finding was not supported by another study carried out among 319 nos. of Colombo school children aged 5- 15 years, 10.7 and $13.0 \%$ of male and female students were having abnormal BMI (7). However, in another study carried out in 2018 among 14 to 15 -year-old schoolchildren in the Colombo education zone shared that prevalence of overweight and obesity among adolescents was revealed as $10.8 \%(\mathrm{CI} 9.3-12.5)$ and $3.9 \%(\mathrm{CI}$ 3.1-5.0) respectively, with no gender difference (8). Further, in another study carried out among girls aged between 14 and 19 years studying in a national school of Batticaloa, the prevalence of obesity and overweightwere $5.5 \%$ and $9.4 \%(9)$. Anyhow, obesity was more prevalent in females than males and females are more vulnerable to develop obesity-related adverse health outcomes in future (10).

Living in small house, a large number of family members, low monthly income and maternal employment were significantly associated with undernutrition among school children (11). But in this current study, the living style of the students did not have a statistically significant association with BMI.

Further, Science stream students have the chance to be provided with adequate knowledge regarding healthy body weight maintenance. In this study also, the prevalence of normal BMI was high among the students who were studying in schools having advanced level science stream classes. However, the type of school did not have a statistically significant association with BMI of the students. Facilities available in schools such as counselling and health club may help the students and their parents to diag- nose and treat obesity earlier. But in this study, such facilities were not sufficient to protect the students from becoming obese .

Nutrient deficiencies may contribute to fat deposition, and vitamin $\mathrm{A}$ and $\mathrm{C}$ are significantly lower in obese persons when compared to healthy individuals. In this current study, More abnormal BMI was recorded among the students who received vitamin C. Further, iron deficiency is a common finding among obese patients (12) and folate levels might be influenced by metabolism alteration, which can occur in obesity (13). But in this study, iron supplementation was effective for protection from abnormal BMI distribution, while folic acid supplementation was not useful to reduce abnormal BMI among students. However, no statistical significant association was found between supplementation of nutrients and obesity status.

Having abnormal BMI is one of the factors that could affect the performance of school-aged students (14). However, in this current study, among the students took part in extracurricular activities and sports meet, the incidence of abnormal BMI was high.

It's agreed with one of the study carried out among students aged 5- 15 years studying in Negombo schools where prevalence of obesity identified by body fat content was high and reported that as validity of internationally developed anthropometric cut- offs in South Asian children is unsatisfactory; locally regionally developed anthropometric tools should be used for screening of obesity (15). Further, South Asian countries face a double burden of malnutrition characterized by high prevalence of underweight, overweight, and obesity. Understanding the distribution of this public health problem is important to tailor targeted interventions for communities (16)

\section{Conclusion}

Nearly $47.2 \%$ of the children in the schools have abnormal BMI. None of the school-based interventions was adequate to change the problem. Hence, relevant stakeholders should take appropriate inter- 
ventions at the school level to reduce the prevalence of thinness, overweight and or obesity among the school students for their better future.

Abbreviations: (G.C.E O/L)- General Certified Examination/ Ordinary Level, (G.C.E A/L)- General Certified Examination/ Advanced Level, SPSS- Statistical Package for Social Sciences, CI- Confidence Interval, BMI- Body Mass Index

\section{Acknowledgement}

The authors would like to acknowledge University Research Grant of University of Jaffna, Sri Lanka and staffs of Department of Community and Family Medicine, Faculty of Jaffna, University of Sri Lanka- Mrs. V. Sureskumar (Technical Officer), Mr.K. Mathusuthan (Technical Officer), Mr.V. Premakumar (Public Health Inspector), Miss.T. Rasiah (Public Health Nursing Sister). Special thanks go to the school societies of Government schools of Jaffna district, Sri Lanka.

\section{Conflicts of Interest}

There are no conflicts of interest

\section{Reference}

1. WHO | Overweight and obesity. WHO [Internet]. 2017 [cited 2020 Nov 29]; Available from: http://www.who.int/gho/ncd/risk_factors/overweight_adolescents_text/en/

2. Akseer N, Al-Gashm S, Mehta S, Mokdad A, Bhutta ZA. Global and regional trends in the nutritional status of young people: a critical and neglected age group [Internet]. Vol. 1393, Annals of the New York Academy of Sciences. Blackwell Publishing Inc.; 2017 [cited 2020 Nov 29]. p. 3-20. Available from: https://pubmed.ncbi.nlm.nih. gov/28436100/

3. Scrimshaw NS, SanGiovanni JP. Synergism of nutrition, infection, and immunity: An overview [Internet]. Vol. 66, American Journal of Clinical Nutrition. American Society for Nutrition; 1997 [cited 2020 Nov 29]. Available from: https://pubmed.ncbi.nlm.nih. gov/9250134/
4. Best C, Neufingerl N, Van Geel L, Van Den Briel T, Osendarp S. The nutritional status of school-aged children: Why should we care? Food Nutr Bull [Internet]. 2010 [cited 2020 Nov 29];31(3):400-17. Available from: https://pubmed.ncbi.nlm.nih.gov/20973461/

5. Family Health Bureau Sri Lanka. School Health Programme [Internet]. Vol. 66, Ministry of Health Sri Lanka. 2012 [cited 2020 Nov 29]. p. 37-9. Available from: https://fhb. health.gov.lk/images/FHB resources/School Health/circular/School Health Programme circular 2016 - English.pdf

6. WHOAnthroPlus Software. Growth reference data for 5-19 years [Internet]. WHO. 2020 [cited 2020 Nov 29]. Available from: https:// www.who.int/toolkits/growth-reference-datafor-5to19-years

7. Wickramasinghe VP, Arambepola C, Bandara P, Abeysekera M, Kuruppu S, Dilshan P, Dissanayake BS, 2017. Use of Waist to Height Ratio in assessing metabolic derangements among normal and overweight/obese 5-15 year old individuals, Ceylon Journal of Medical Science 54 (1):18-26

8. Hettiarachchi J, Jayatissa R, Wickramasinghe SC , Wijewardena K (2018). Overweight and obesity among adolescent school children in the Colombo education zone, Journal of the Postgraduate Institute of Medicine; 5 (1): 63: $1-7$

9. Karuppiah, D. and Markandu, M., 2018. Prevalence of obesity, overweight and central obesity among adolescent girls in national school in Batticaloa district, Sri Lanka. Sri Lanka Journal of Diabetes Endocrinologyand Metabolism, 8(1).17-22

10. Jayawardana NWIA, Jayalath WATA, Madhujith WMT, Ralapanawa U, Jayasekera RS, Alagiyawanna SASB, Bandara AMKR and Kaluphana NS (2017). Lifestyle factors associated with obesity in a cohort of males in the 
central province of Sri Lanka: a cross-sectional descriptive study, BMC Public Health, 17: 27. Published online 2017 Jan 5

11. Galgamuwa L, Iddawela D, Dharmaratne S, Galgamuwa G. (2017). Nutritional status and correlated socio-economic factors among preschool and school children in plantation communities, Sri Lanka. BMC Public Health. 17: 377 .

12. Arshad M, Jaberian S, Pazouki A, Riazi S, Rangra MA, Mokbber S. Iron deficiency anemia and megaloblastic anemia in obese patients. 2017 Mar 1: Rom J Intern Med; 1 (55); 3-7

13. Bird JK, Ronnenberg AG, Choi SW. 2015 Obesity is associated with increased red blood cell folate despite lower dietary intakes and serum concentrations. J Nutr 145, 79-86.
14. Angela S, Deborah AS, Good J. Increased body weight affects academic performance in university students, Preventive Medicine reports, 5 ; 220-23

15. Warnakulasuriya LS, Fernando MAM, 1 Adikaram AVN, Thawfeek ARM, Anurasiri WML, Elisabet R, Bergsten P, Silva KDR, Samaranayake DL, Wickramasinghe VP. Assessment of Nutritional Status in Sri Lankan Children: Validity of Current Anthropometry Cutoffs? 31 (7), 633-642. Asia Pacific journal of public health.

16. Somasundaram N, Ranathunga, I, Gunawardana K, Ahamed M, Ediriweera Antonypillai CN and Kalupahana N (2019). High Prevalence of Overweight/Obesity in Urban Sri Lanka: Findings from the Colombo Urban Study, Journal of Diabetes Research, Article ID 2046428, 1 - 9 